Acta Universitatis Wratislaviensis • No 3982

Literatura i Kultura Popularna XXV, Wrocław 2019

https://doi.org/10.19195/0867-7441.25.10

Michał Wolski

ORCID: 0000-0003-1563-8878

Uniwersytet Wrocławski

\title{
Poziomy wzajemnych oddziaływań w supersystemie rozrywkowym Marvel Cinematic Universe
}

\begin{abstract}
Słowa kluczowe: Marvel, MCU, superbohater, uniwersum, komiks, Kinowe Uniwersum Marvela
\end{abstract}

Keywords: Marvel, MCU, superhero, universe, comics, Marvel Cinematic Universe

\section{Wprowadzenie}

Marvel Cinematic Universe - albo Kinowe Uniwersum Marvela - to przykład jednego z bardziej fascynujących i obecnie (stan na 2017 rok) niesamowicie popularnych supersystemów rozrywkowych. Za jego podstawę należy uznać serię filmów kinowych produkowanych przez firmę Marvel Studios, które z kolei są luźnymi adaptacjami przygód komiksowych bohaterów Marvela ${ }^{1}$ — jednego z dwóch najstarszych i największych wydawnictw amerykańskich specjalizujących się w tematyce superbohaterskiej ${ }^{2}$. Oficjalnie komiksowe uniwersum bohaterów Marvela oraz jego filmowy odpowiednik są bytami rozłącznymi. Potwierdza to zresztą,

${ }^{1}$ Szerzej piszę o tym w M. Wolski, Kino przerysowane. Strategie przenoszenia komiksów na ekran na przykładzie filmów firmy Marvel Studios, [w:] Bękarty X muzy. Filmowe adaptacje materiałów nieliterackich, red. P. Duziński, R. Dudziński, K. Kowalczyk, Wrocław 2015, s. 11-28.

${ }^{2}$ Marvel oraz konkurencyjne DC w czerwcu 2017 roku kontrolowały 74,58\% rynku komiksowego w USA (w zależności od koniunktury i tematyki proporcje między liczbą a sprzedażą poszczególnych tytułów mogą się różnić, jednak udział obu firm w rynku jest mniej więcej stały), podczas gdy trzecie największe wydawnictwo - Image Comics — przy 40 wydawanych tytułach zajmowało jedynie 9\% rynku. Z reguły też Marvel wydaje o około jednej trzeciej komiksów więcej niż DC; por. June 2017 Comic Book Sales to Comics Shops, http://www.comichron.com/monthlycomicssales/2017/2017-06.html (dostęp: 24.07.2017). 
dokonane w 2015 roku, wydzielenie ze struktury firmy Marvel Entertainment oddziału Marvel Studios, odpowiedzialnego wyłącznie za produkcje kinowe ${ }^{3}$. Zachodzą jednak między nimi wszelkiego rodzaju nawiązania, przekształcenia i inne oddziaływania, dzięki którym Kinowe Uniwersum Marvela (które skrótowo będę określać też mianem MCU — od Marvel Cinematic Universe) jako supersystem rozrywkowy nie tylko jest w stanie utrzymać swojąa atrakcyjność w oczach odbiorców, lecz także ją pogłębiać.

W niniejszym tekście chciałbym skupić się właśnie na tych oddziaływaniach oraz na ich konsekwencjach dla zrozumienia, czym jest system rozrywkowy MCU i jak wyglądają wzajemne relacje składających się na niego elementów. Postaram się również odpowiedzieć na pytanie, w jaki sposób czynniki pozatekstowe (przede wszystkim rozumiane jako kwestie prawne, marketingowe oraz konsumpcyjne) wpływają na sposób jego rozwoju. Najpierw jednak chciałbym przyjrzeć się kategorii samego supersystemu rozrywkowego oraz rozważyć jej adekwatność w stosunku do Kinowego Uniwersum Marvela.

\section{Garść rozważań metodologicznych}

Tomasz Żaglewski w analizie współczesnego filmu komiksowego pod tytułem Kinowe uniwersum superbohaterów postuluje używanie w kontekście filmów Marvela (i nie tylko) kategorii „uniwersum”, rozumianej jako metanarrację (najczęściej filmowo-komiksową), zorientowaną między trzema wyznacznikami uniwersalności, które może realizować w określonych odsłonach w różnym stopniu. Chodzi o strukturę nazwaną przez Żaglewskiego „trójkątem uniwers-alnym”, odnoszącą się do trzech elementów (czy też filarów) niezbędnych, aby daną filmowo-komiksową metanarrację określić mianem uniwersum. Mowa o „gatunkowej hybrydyzacji/fraktalizacji, paratekstualności oraz transmedialności" ${ }^{\text {; }}$ dana struktura metanarracyjna musi dążyć też do „odpowiedniego zbilansowania i utrzymywania danego zbioru tekstów w obszarze ograniczonym przez wszystkie trzy wspomniane składniki"'5.

Metodologiczna propozycja Żaglewskiego jest tu przeze mnie wskazywana z dwóch powodów. Przede wszystkim rodzi się pokusa, żeby kategorii uniwersum — czy struktur uniwersalnych — używać zamiennie z pojęciem supersystemu rozrywkowego, oba terminy bowiem w pewnym stopniu się pokrywają. Zbigniew

${ }^{3}$ Wprawdzie za rozłączeniem tych dwóch firm stały przede wszystkim względy osobiste, to sam fakt uzyskania autonomii przez studio filmowe świadczy o jego rosnącym znaczeniu względem innych produkcji i projektów Marvela; por. M. Ochnik, \#2351 - Marvel podzielony, http://kolorowezeszyty. blogspot.com/2017/07/2351-marvel-podzielony.html (dostęp: 24.08.2017).

${ }^{4}$ T. Żaglewski, Kinowe uniwersum superbohaterów. Analiza wspótczesnego filmu komiksowego, Warszawa 2017, s. 79.

5 Ibidem. 
Wałaszewski mówi wprost o „uniwersum tekstów supersystemu”, choć — jak się wydaje - rozumie on ten termin bardziej potocznie. Sam Żaglewski rozprawia się z pozorną wtórnością kategorii uniwersum względem innych pojęć używanych w humanistyce - przede wszystkim „światoopowieścią” (ang. storyworld) oraz „franczyzą"” — pomija jednak termin „supersystem rozrywkowy”, który wypada tutaj odróżnić od - skądinąd znakomicie opisującej zjawiska funkcjonujące w ramach MCU — „struktury uniwers-alnej”. Obie propozycje terminologiczne rozmijają się przynajmniej w czterech zasadniczych punktach.

1. Pojęcie „supersystemu rozrywkowego" wydaje się przede wszystkim pojemniejsze od koncepcji „struktury uniwers-alnej”, która skupia się głównie na zagadnieniach o charakterze narracyjnym. Jakkolwiek więc takie kwestie, jak intertekstualność (lub transmedialność), hybrydyzacja gatunkowa czy paratekstualność, służą spajaniu struktur fabularnych wewnątrz supersystemu, to na nich się on bynajmniej nie zamyka. Jak pisze Zbigniew Wałaszewski:

Zwykle w nowych tekstach kultury, pretendujących do roli inicjatorów supersystemu rozrywkowego, można wskazać równocześnie oba rodzaje odwołań: kilka wpływających na warstwę semantyczną utworu i znaczną liczbę takich, które służą grze w rozpoznawanie. Wszystkie cytaty, niezależnie od ich rodzaju i liczby, powinny zostać harmonijnie włączone w obręb utworu, aby pozostał on spójny, wyrazisty, odrębny i jednocześnie otwarty na przepływy znaczeń z jak najszerszego obszaru kultury popularnej oraz łatwo rozpoznawalnych utworów i zjawisk kultury elitarnej ${ }^{8}$.

2. Ze względu na ową różnorodność elementów supersystem rozrywkowy zdaje się stopniować poziomy istotności swoich elementów i pozwala na pewien stopień dowolności w ich dobieraniu; stąd operowanie na większej liczbie mediów oraz silny nacisk położony na ofertę komercyjną. Koncepcja „uniwersum” odnosi się przede wszystkim do tej części supersystemu, która jest zjawiskiem narracyjno-partycypacyjnym ${ }^{9}$, w ujęciu Żaglewskiego sprowadzającym się (ze względu na specyficzne zabiegi narracyjne) do mediów filmowych i komiksowych.

3. Z tego wynika, że supersystem rozrywkowy w ujęciu Marshy Kinder obejmuje również struktury tekstowe o charakterze nienarracyjnym, rozumiejąc „intertekstualność jako narzędzie utowarowienia. W określonych społecznych i ekonomicznych kontekstach rozpoznanie specyficznych aluzji prowadzi do wygenerowania zysku opartego na intertekstualności - szczególnie zysku komercyjnego" ". Inaczej mówiąc, supersystem rozrywkowy jest w stanie generować potrzeby natury konsumpcyjnej. Uniwersum filmowo-komiksowe również, ale właśnie jako element supersystemu.

${ }^{6}$ Z. Wałaszewski, Wiedźmin: pierwszy polski supersystem rozrywkowy, [w:] Obraz literatury w komunikacji społecznej po roku '89, red. A. Werner, T. Żukowski, Warszawa 2013, s. 129.

7 T. Żaglewski, op. cit., s. 71.

8 Z. Wałaszewski. op. cit, s. 133.

9 Por. T. Żaglewski, op. cit., s. 243.

10 M. Kinder, Playing with Power in Movies, Television, and Video Games. From Muppet Babies to Teenage Mutant Ninja Turtles, Berkeley 1991, s. 45; jeśli nie podano inaczej, przeł. M.W. 
4. Koncepcja Kinder podkreśla jeszcze jeden aspekt, szczególnie istotny w kulturze konwergencji. Chodzi o potencjał socjalizacyjny wykraczający poza partycypację w metanarracji, ale prowadzący do oddolnego tworzenia się społeczności ${ }^{11}$. Na zasadzie tropienia nawiązań intertekstualnych uczestnik sytuacji komunikacyjnej z danym tekstem kultury (wchodzącym w skład supersystemu rozrywkowego) jest zachęcany nie tylko do śledzenia kolejnych zależności, lecz pośrednio także do tworzenia własnych. Sprzyja to interaktywnemu — a docelowo też interakcyjnemu ${ }^{12}$ — podejściu do supersystemu, mogącemu przybierać najróżniejsze formy — od dyskusji z innymi entuzjastami danej rozrywki po najróżniejszą twórczość fanowską i cosplay. Prowadzić to może do wykształcenia swego rodzaju „nowoplemion” - posługując się terminem Michela Maffesoliego $^{13}$ - których członkowie są w stanie zdobywać prestiż poprzez inwestycję czasu i/lub pieniędzy w swoje zainteresowania (gdzie zainwestowanie czasu zawsze będzie waloryzowane wyżej).

Uzasadnione będzie zatem stwierdzenie, że choć uniwersa filmowo-komiksowe mogą być elementem czy wręcz podstawą supersystemów rozrywkowych — i jak się wydaje, tak właśnie jest w wypadku MCU — sama struktura relacji między poszczególnymi elementami, supersystemu może być dalece bardziej złożona niż to, co może zachodzić między wierzchołkami „trójkąta uniwers-alnego”. Zarazem więc $\mathrm{w}$ ramach supersystemu rozrywkowego mogą zachodzić relacje między różnymi elementami, niekoniecznie zapośredniczonymi w podstawie narracyjnej, jaką jest film czy komiks, jak też tymi (szeroko rozumianymi) tekstami kultury, które są stricte fanowską recepcją — nie tylko w formie recenzji, omówienia czy fanfilmu (a więc dzieł o charakterze narracyjnym), lecz także na przykład własnoręcznie zrobioną figurką czy kostiumem.

Drugim powodem przywołania przeze mnie kategorii uniwersum jest to, że — poczyniwszy wskazane rozróżnienia — bardzo dobrze oddaje ona charakter różnorodnych relacji pomiędzy wchodzącymi w skład danego supersystemu rozrywkowego poziomami narracji, czy to o charakterze tekstowym, paratekstowym, czy wreszcie - metatekstowym. Dlatego w dalszych rozważaniach będziemy poruszać się w ramach jednego supersystemu MCU, ale między różnymi uniwersami czy to filmowymi, czy to serialowymi, komiksowymi i innymi.

Dodatkowo - w imię przejrzystości wywodu — skupimy się przede wszystkim na narracyjnych tekstach kultury wchodzących w skład supersystemu, niejako na uboczu pozostawiając kwestie gadżetów i innych aspektów sfery komercjalizacji interesującej nas metanarracji. Podstawową przesłanką ku temu jest niewielki stopień oddziaływania tego typu elementów na narracyjną sferę MCU, które dodatko-

11 Por. ibidem.

12 R. Kluszczyński, Interaktywność - właściwość odbioru czy nowa jakość sztuki/kultury, [w:] Estetyczne przestrzenie wspótczesności, red. A. Zeidler-Janiszewska, Warszawa 1996, s. 143.

13 M. Maffesoli, Czas plemion. Schytek indywidualizmu w społeczeństwach ponowoczesnych, red. B. Fatyga, przeł. M. Bucholc, Warszawa 2008, s. 11. 
wo nie różnią się w żaden szczególny sposób od analogicznych aspektów innych supersystemów rozrywkowych (na przykład Gwiezdnych wojen). Z kolei kwestie produkcyjne i wszelkiego rodzaju parateksty wokół MCU to temat tak rozległy, że wprowadzenie tych wątków do artykułu nie tylko istotnie zwiększyłoby jego objętość, lecz także byłoby z konieczności (zbyt) powierzchowne (w pewnym stopniu kwestie te zostały poruszone w antologii Marvel Comics into Film z 2016 roku $^{14}$, choć nadal wydaje się, że nie wyczerpano tam tego zagadnienia). Wobec tego skupiać się będziemy na kwestiach dotyczących transmedialności i zależności między narracjami, sprawy merkantylno-produkcyjne pozostawiając na osobne rozważania.

\section{Specyfika supersystemu MCU}

Jak słusznie zauważa Wałaszewski, u podstaw wszelkich metanarracji aspirujących do miana supersystemów rozrywkowych da się zauważyć ,zjawisko dominacji — w obrębie systemów tekstowych — filmu fabularnego jako medium o największym zasięgu, najatrakcyjniejszym (za sprawą audiowizualności) sposobie komunikacji i najłatwiej przyswajalnych treściach" ${ }^{15}$. Dlatego też o supersystemie MCU możemy mówić dopiero od 30 kwietnia 2008 roku, kiedy na ekrany kin w Stanach Zjednoczonych wszedł film Iron Man (reż. J. Favreau, USA) — pierwsza produkcja otwarcie skonstruowana jako punkt wyjścia filmowo-komiksowego uniwersum. Przeniosła ona na srebrny ekran postać Tony'ego Starka (Robert Downey Jr), multimilionera i producenta broni, który po traumatycznych przeżyciach w Afganistanie postanawia zmienić świat i staje się superbohaterem. Film jest adaptacją komiksów o Iron Manie - który zadebiutował w marcu 1963 roku w 39. zeszycie komiksu Tales of Suspense publikowanego przez wydawnictwo Marvel - uwspółcześnia też i uaktualnia niektóre wątki narracyjne i fabularne komiksowego pierwowzoru. Warto na jego przykładzie zaobserwować dwa zjawiska.

Przede wszystkim mimo ponad czterdziestoletniej obecności na kartach komiksów (oraz okazjonalnych występów w telewizji - Iron Man doczekał się bowiem dwóch sezonów serialu animowanego Iron Man - obrońca dobra [Iron Man: The Animated Series, reż. B. Arkwright et al., USA 1994-1996] oraz kilku gościnnych występów w animacjach o innych superbohaterach Marvela) ${ }^{16}$ to nie

14 Por. Marvel Comics into Film: Essays on Adaptations Since the 1940s, red. M.J. McEniry, R.M. Peaslee, R.G. Weiner, Jefferson 2016. Przede wszystkim kwestie te porusza Eric Garneau w swoim szkicu Dare to be stupid: The fetishization of heavy metal and the new in Transformers: the Movie (s. 52-59) na przykładzie filmu, który wprawdzie nie jest częścią MCU, ale został wyprodukowany przez Marvela i funkcjonował na podobnej zasadzie sprzężenia zwrotnego z rynkiem zabawek co późniejsze produkcje z interesującego nas supersystemu rozrywkowego.

15 Z. Wałaszewski. op. cit., s. 129.

16 Postać ta pojawiała się też okazjonalnie w niektórych grach wideo opartych na komiksach Marvela; por. Iron Man in other Media, https://en.wikipedia.org/wiki/Iron_Man_in_other_media (dostęp: 2.08.2017). 
rodzime medium stanowi podstawę supersystemu rozrywkowego, lecz właśnie film fabularny, posługujący się środkami narracyjnymi daleko bardziej angażującymi uwagę odbiorcy niż komiks czy literatura ${ }^{17}$. Zarazem jednak medium pierwotne (komiks) nie ulega marginalizacji, wręcz przeciwnie; zgodnie z przywoływanym przez Żaglewskiego (za Henrym Jenkinsem) postulatem transmedialności między filmem a komiksem zachodzi swego rodzaju sprzężenie zwrotne. Film korzysta z medium pierwotnego jako źródła postaci, rozwiązań narracyjnych, rekwizytów czy wreszcie wątków fabularnych, niejednokrotnie jednak dostarcza komiksom tego samego. Widać to zarówno w wypadku wizerunku postaci Iron Mana — którą rysownicy Marvela od momentu rozpoczęcia produkcji filmu coraz bardziej zaczęli upodabniać do Downeya Jr. - ale też innych bohaterów Marvela, których odpowiedniki pojawily się na srebrnych ekranach. Najbardziej jaskrawym przykładem jest bodaj postać Yondu, dzielnego błękitnoskórego łucznika z komiksów $\mathrm{z}$ serii Guardians of the Galaxy $\mathrm{z}$ lat dziewięćdziesiątych, będącego członkiem kosmicznej drużyny Avengers z roku 3000. Postać ta została w bardzo luźny sposób zaadaptowana do filmu Strażnicy Galaktyki (Guardians of the Galaxy, reż. J. Gunn, USA 2014) jako cyniczny, egocentryczny przywódca kosmicznych piratów. Na podstawie filmowego wizerunku zmieniono wygląd i charakter tej postaci w komiksach i już wkrótce po premierze obrazu Gunna w komiksie Legendary Star-Lord Sama Humphriesa i Steve'a McNivena pojawiła się nowa wersja Yondu, wyraźnie odwołująca się do filmowego wyobrażenia (por. rycina 1).
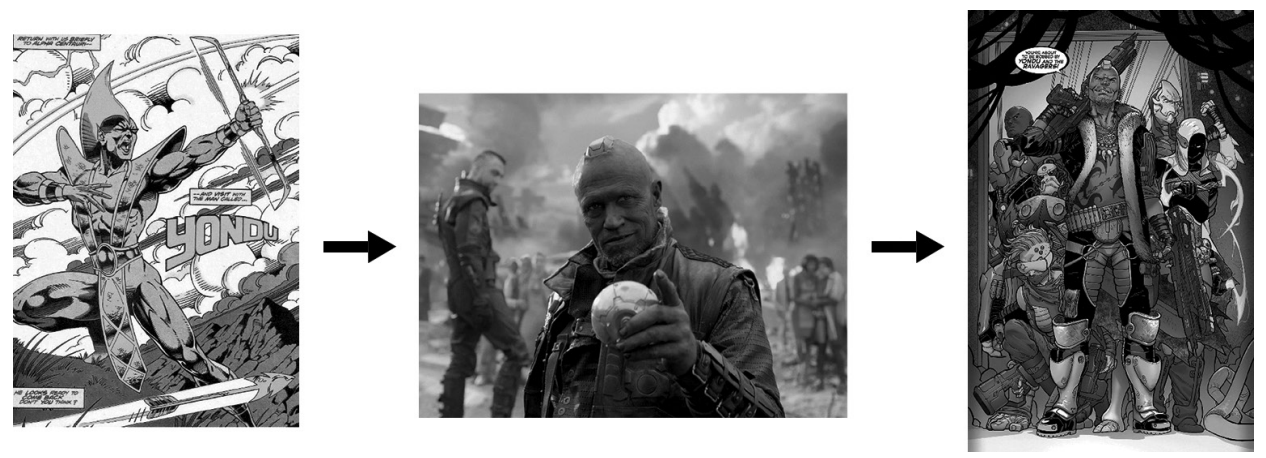

Rycina 1. Ewolucja komiksowej postaci Yondu zaprośredniczona przez wyobrażenie filmowe

Źródło: opracowanie własne z wykorzystaniem kadrów z komiksów M Callages, C. Doran, „Guardians of Galaxy Annual” 1993, nr 3; S. Humpries, J Garrón, „Star-Lord” 2015, nr 2 oraz filmu Strażnicy Galaktyki

(Guardians of Galaxy, reż. J. Gunn, USA 2014).

Drugim interesującym nas zjawiskiem jest to, że przed Iron Manem powstało wiele filmowych i telewizyjnych adaptacji komiksów Marvela, jednak dopiero od 2008 roku możemy mówić o supersystemie MCU. Wynika to z faktu, że najczęściej wcześniejsze filmy Marvela... nie były produkowane przez Marvela.

17 W Polsce znakomitym przykładem tej tendencji jest supersystem rozrywkowy wokół uniwersum Wiedźmina, którego centralnym tekstem jest współcześnie nie cykl Andrzeja Sapkowskiego, a gry wideo firmy CD Projekt RED. 
Po kryzysie na rynku komiksowym w drugiej połowie lat dziewięćdziesiątych i związanym z tym widmie bankructwa Marvela wydawnictwo odsprzedało prawa do [części] swoich postaci do Hollywood, czym zapewniło sobie alternatywne źródło dochodów, mając niepewną nadzieję na rychłe odrodzenie ${ }^{18}$.

Dlatego też część praw do filmowych adaptacji przygód różnych bohaterów — przede wszystkim Spider-Mana, Punishera, Man-Thinga, Daredevila, drużyn X-Men i Fantastycznej Czwórki — od tego czasu spoczywało w rękach różnych wytwórni (trzej pierwsi superbohaterowie należeli odpowiednio do wytwórni Columbia, Lionsgate i Universal, pozostali do 20th Century Fox) i żadnej z nich nie zależało na tworzeniu filmowo-komiksowego uniwersum, które miałoby stać się zalążkiem supersystemu rozrywkowego ${ }^{19}$. Dopiero Marvel Studios za pomoca określonych środków narracyjnych i dzięki umiejętnemu posługiwaniu się paratekstami (zwiastunami, scenami po napisach itp.) ${ }^{20}$ zdołało wyjść poza formułę pojedynczego filmu czy ich serii.

Początek był relatywnie banalny — różne filmy reprezentujące poszczególne franczyzy zaczęły mimochodem nawiązywać do siebie nawzajem. Marvelowi a tak naprawdę szefowi Marvel Studios, Kevinowi Feige'owi — udało się jednak konsekwentnie rozwijać te nawiązania w stronę produkcji od siebie współzależnych, co robi do dziś, nawet pomimo że studio posiada jedynie prawa do części swojej własności intelektualnej (na rycinie 2 widać, jak wyglądała kwestia wykorzystania praw do poszczególnych postaci w 2017 roku). Warto zwrócić uwagę, że Marvel konsekwentnie stara się odzyskać prawa do filmowych adaptacji przygód swoich superbohaterów, czego niejednokrotnie domagają się też fani. Ponieważ dokładna treść umów między Marvel Entertainment a innymi wytwórniami nie jest jednak jawna, to roztrząsanie, które prawa należą do kogo i co można z nimi zrobić, jest jedną z ulubionych aktywności bardziej zagorzałych wielbicieli MCU ${ }^{21}$.

Trzonem supersystemu rozrywkowego Kinowego Uniwersum Marvela są więc filmy produkowane przez Marvel Studios od 2008 roku, funkcjonujące w swego rodzaju obustronnie korzystnej relacji z komiksowymi odpowiednikami narracji superbohaterskich. Uniwersum komiksowe jest w tej relacji przede wszystkim punktem odniesienia (ze względu na mniejszy zasięg niż filmy), jednak jako takie zajmuje miejsce blisko centrum supersystemu. $Z$ punktu widzenia spójności narracyjno-fabularnej kolejnym poziomem będą zatem seriale telewizyjne, seriale internetowe, krótkometrażowe etiudy dołączane do wydań DVD i Blu-Ray (tak zwane one-shots) oraz komiksowe uzupełnienia, najczęściej w formie preludiów do określonych fil-

18 D. Johnson, Cinematic Destiny: Marvel Studios and the trade stories of industrial convergence, „Cinema Journal” 52, 2012, s. 1.

19 Dokładniej przedstawiają tę kwestię Martin Flanagan, Mike McKenny i Andrew Livingstone, The Marvel Studios Phenomenon: Inside a Transmedia Universe, London 2016, s. 4-6.

20 Por. D. Johnson, op. cit., s. 5-9.

21 Por. Ł. Stelmach, Dlaczego Fox powinien sprzedać prawa Marvelowi?, http://ichabod.pl/ dlaczego-fox-powinien-sprzedac-prawa-marvelowi/ (dostęp: 2.08.2017). 


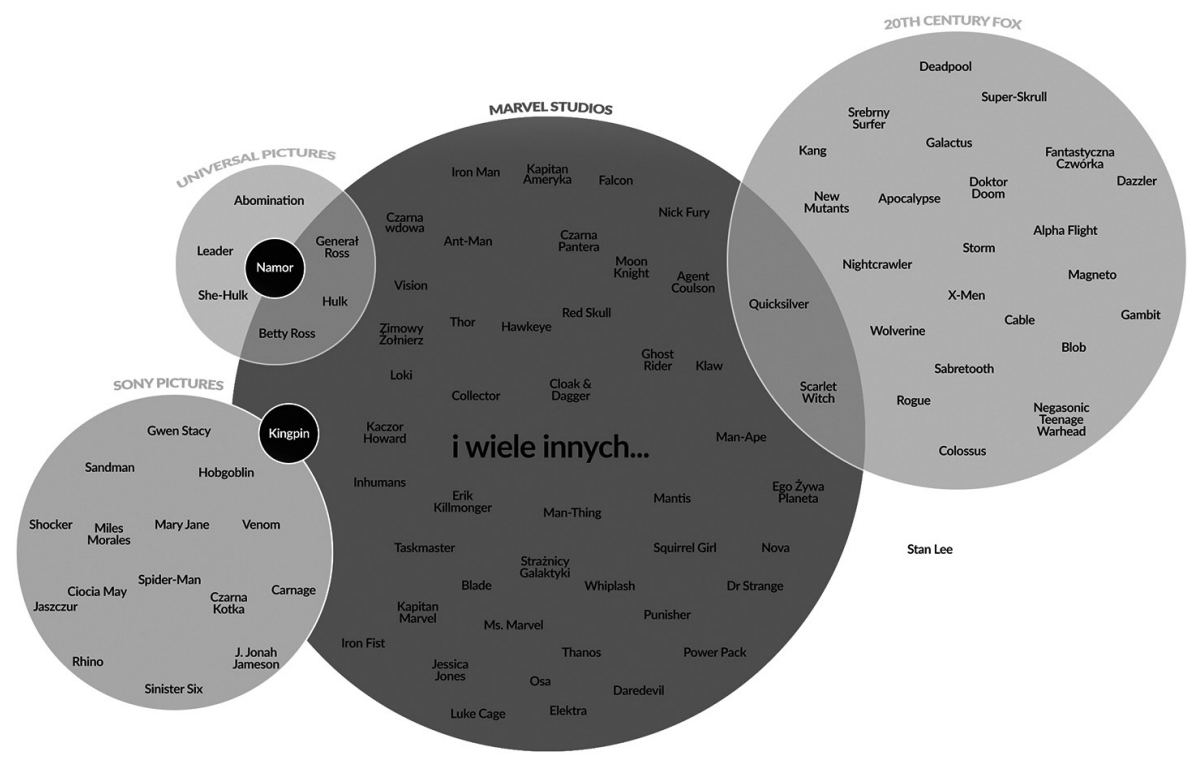

Rycina 2. Infografika prezentującą kwestie praw do filmowych adaptacji przygód poszczególnych postaci Marvela

Źródło: opracowanie własne na podstawie M. Mitchell, Visual Guide to Marvel Character Movie Right, http:// bit.ly/lirAcVs (dostęp: 13.04.2017).

mów ${ }^{22}$. Ich znaczenie i funkcjonalność w ramach metanarracji MCU zmieniała się z czasem; początkowo to komiksy były głównym uzupełnieniem fabuł filmowych (przede wszystkim związanych z obrazami o Iron Manie i Kapitanie Ameryce, ale też rozwijającym na przykład postać Czarnej Wdowy w Black Widow Strikes Freda Van Lente czy ideę stojącą za Inicjatywą Avengers w Avengers Prelude: Fury's Big Week Chrisa Yosta). Z kolei kilkuminutowe one-shots — zwłaszcza dwa pierwsze, Konsultant (The Consultant, reż. Leythum, USA 2011) oraz Ciekawa rzecz spotkała nas przy mlocie Thora (A Funny Thing Happened on the Way to Thor's Hammer, reż. Leythum, USA 2011) — służyły przede wszystkim jako uzupełnienia pewnych fabularnych nieścisłości, które mogły pojawić się między filmami.

Po premierze filmu Iron Man 3 (reż. S. Black, USA 2013) funkcję tę przejęły przede wszystkim seriale telewizyjne: Agenci T.A.R.C.Z.Y. (Agents of S.H.I.E.L.D., reż. J. Whedon et al., USA 2013) oraz w nieco mniejszym stopniu Agentka Carter (Agent Carter, reż. J. Getzinger et al., USA 2015-2016). W obu przypadkach bardzo istotnym założeniem konstrukcyjnym prezentowanych fabuł jest reagowanie na bieżące wydarzenia przedstawiane w filmach kinowych i dopowiadanie oraz rozwijanie podjętych w nich wątków. Podobną funkcję mają seriale i spo-

22 Por. V. Pellizzi, Entertainment Marketing Strategy: Transmedia Storytelling, Marvel and the Reinvention of the Entertainment Franchise, praca napisana pod kierunkiem B. Mierzejewskiej, Fordham University, New York 2015, s. 16. 
ty internetowe udostępniane za pośrednictwem serwisu YouTube - Agents of S.H.I.E.L.D.: Slingshot (USA 2016) rozwijał wątek jednej z drugoplanowych postaci z serialu Agenci T.A.R.C.Z.Y., Eleny Rodriguez, natomiast seria spotów WHIH Newsfront to fikcyjne materiały informacyjne wprowadzające w wydarzenia z filmów kinowych poprzez poetykę telewizyjnych wiadomości ${ }^{23}$.

Na tym poziomie mieszczą się (lub będą się mieścić) także inne seriale telewizyjne, które wprawdzie nie wiążą się bezpośrednio z fabułami filmowymi, ale - co jest podkreślane wielokrotnie - opowiadają historie dziejące się w tym samym świecie przedstawionym. Dotyczy to zarówno wszystkich pięciu seriali powstałych w koprodukcji Marvela z platformą Netflix, charakteryzujących się utrzymaniem reguł funkcjonowania telewizji jakościowej ${ }^{24}$, jak i projektowanych seriali młodzieżowych i komediowych. Przede wszystkim chodzi tu o oparty na kultowym komiksie Briana K. Vaughna serial The Runaways Josha Schwartza i Stephanie Savage (planowany na listopad 2017 roku) oraz wpisujący się w konwencję sitcomu The New Warriors Kevina Biegela (który ma ukazać się w 2018 roku). Wszystkie te produkcje, mimo znacznej autonomii, w sposób fabularny oraz — przede wszystkim - marketingowy podlegają podstawowej metanarracji, jaką są filmy kinowe, odnosząc się do nich czy to przez powtórzenie, czy też zanegowanie (jak w wypadku seriali Netfliksa) określonych rozwiązań narracyjnych, strukturalnych czy wreszcie fabularnych. Główną zasadą konstrukcyjną jest tutaj postulowana przez Jenkinsa wielość alternatywnych punktów widzenia ${ }^{25}$, która wprawdzie nie jest opowiadaniem transmedialnym w takim sensie jak przytaczany przez niego przykład związany z uniwersum Matriksa ${ }^{26}$, zdecydowanie jednak spełnia warunek „opowiadania synergicznego", w którym dodatkową satysfakcję odbiorcy generuje obcowanie z mniej znanymi czy oczywistymi, ale równoważnymi pod względem fabularnym tekstami kultury konstytuującymi daną metanarrację.

MCU istnieje dzięki ciągłości (a ściślej — radykalnej intertekstualności), która dostarcza potencjalnych kontynuacji zawierających różne (subiektywne) punkty widzenia. Serialowość MCU jest tym, co pozwala zaludnić różne rejony tego samego uniwersum (światoopowieści), a jego multimodalna natura wpływa na atrakcyjność w oczach różnych widowni ${ }^{27}$.

${ }^{23}$ Celem tych w gruncie rzeczy marketingowych zabiegów jest wywołanie w potencjalnych odbiorcach immersyjnej przyjemności ze śledzenia poszczególnych wątków zarysowanych w filmach. Efekt ten wspierano dodatkowo na profilu stacji telewizyjnej WHIH na Twitterze — https://twitter. com/whihofficial (dostęp: 2.08.2017).

24 Por. M. Major, Serialowy fan 2.0, „Ekrany” 2012, nr 10, s. 86-87. Autorka rozumie telewizję jakościową jako produkcje zrobione z większą dbałością o aspekty realizacyjne, odpowiednio wysokim budżetem i ciekawym scenariuszem, stawiającym często na rozwiązania nieoczywiste i wymagające od odbiorcy świadomej i uważnej recepcji.

${ }^{25}$ H. Jenkins, Kultura konwergencji. Zderzenie starych i nowych mediów, przeł. M. Bernatowicz, M. Filiciak, Warszawa 2007, s. 177.

26 Ibidem, s. 91-129.

27 Á. Richter, The Marvel Cinematic Universe as a transmedia narrative, „Americana: E-Journal of American Studies in Hungary" 12, 2016, http://americanaejournal.hu/vol12no1/richter (dostęp: 3.08.2017).

Literatura i Kultura Popularna 25, 2019

(C) for this edition by CNS 
Kolejną instancją supersystemu rozrywkowego MCU są narracyjne teksty kultury, które opierają się na jego trzonie pod względem stylistycznym (głównie estetycznym) i marketingowym, jednak nie łączą się z nim fabularnie. Tu trzeba przede wszystkim wymienić wszelkiego rodzaju gry wideo (często korzystające z estetyki filmów, jednak przedstawiające fabuły niejednokrotnie sprzeczne z późniejszymi realizacjami kinowymi lub wręcz otwarcie od nich niezależne), również mobilne (których głównym zadaniem jest podtrzymanie zainteresowania markami związanymi z supersystemem), a także filmy i seriale animowane. Prym wiedzie tutaj przede wszystkim serial Avengers: Zjednoczeni (Avengers Assemble, USA 2013), oparty na filmowym składzie drużyny Avengers oraz ich cechach charakterystycznych, jednak przedstawiający całkowicie niezależne wątki fabularne. Tego typu teksty kultury audiowizualnej mieszczą się w strukturze supersystemu MCU, ponieważ tworzą ,komercyjną, intertekstualną sieć przekazów i produktów (gadżetów) rozwiniętą wokół fikcyjnego bądź rzeczywistego bohatera kultury popularnej"28. Nawet jeśli nie wchodzą w skład filmowo-komiksowego uniwersum (posługując się terminem Żaglewskiego) czy też opowiadania synergicznego (idąc tropem Jenkinsa), to pozwalają potencjalnym odbiorcom - zwłaszcza młodszym - na przedłużony $\mathrm{i}$ intensywny kontakt $\mathrm{z}$ bohaterami, których znają z głównych tekstów kultury wchodzących w skład MCU. W tym miejscu daje o sobie znać silna postaciocentryczność ${ }^{29}$ supersystemów rozrywkowych, zauważona już przez Kinder i podkreślona przez Wałaszewskiego. Zgodnie z nią charakter fabuł czy złożoność świata przedstawionego mają znaczenie niewielkie lub zgoła marginalne, o ile w danej metanarracji występują mocne, wyraziste postacie, z którymi odbiorca może wejść w jaką̧ś formę zażyłości.

Podobną funkcję - obok oczywiście monetyzacji kapitału kulturowego generowanego przez supersystem - mają wszelkiego rodzaju niefabularne teksty kultury w rodzaju ubrań, zabawek, gadżetów i innych przedmiotów opartych na franczyzach powiązanych z MCU, których choćby wymienienie dalece przekracza ambicje niniejszego artykułu.

Ostatnim elementem supersystemu — będącym zarazem jego najniższym poziomem - są wszelkie teksty kultury niebędące oficjalnymi komunikatami twórców MCU, a inicjatywami o charakterze oddolnym, związanymi z szeroko pojętą aktywnością fanów tej metanarracji. Dotyczy to zarówno fanowskich komiksów czy opowiadań, jak i grafik, kostiumów, recenzji, spekulacji na temat przyszłości MCU i wielu innych pól działalności wielbicieli Marvela, które z jednej strony ożywiają zainteresowanie marką, z drugiej zaś pełnią wspomnianą już funkcję socjalizacyj-

28 Z. Wałaszewski, op. cit., s. 128.

29 Używam tego terminu za Marie-Laure Ryan i rozumiem przez niego narracje koncentrujące się na „rozpoznawalnej postaci, która inspiruje jedną opowieść za drugą [i] ma tendencję do bycia typem superbohatera, który nie ewoluuje między epizodami; [...] postaci pokroju Odyseusza, Sherlocka Holmesa, Indiany Jonesa lub Jamesa Bonda" - eadem, Transmedial Storytelling and Transfictionality, http://users.frii.com/mlryan/transmedia.html (dostęp: 8.06.2015). 
ną. Na marginesie tej przestrzeni sytuować się będą także wszelkie teksty kultury wchodzące w różnego rodzaju intertekstualne relacje z MCU; będą to więc zarówno dzieła przywoływane $\mathrm{w}$ filmach $\mathrm{w}$ charakterze cytatu, parodii lub nawiązania (jak choćby remiks utworu Iron Man zespołu Black Sabbath w finale Iron Mana z 2008 roku), jak i inne produkcje filmowe powstałe na licencjach pozwalających na wykorzystanie części własności intelektualnej Marvela (choć w tym wypadku dochodzi raczej do sprzężenia zwrotnego z komiksami niż z filmami Marvel Studios). Całość wzajemnych relacji poszczególnych elementów można przedstawić tak, jak wygląda to na rycinie 3 .

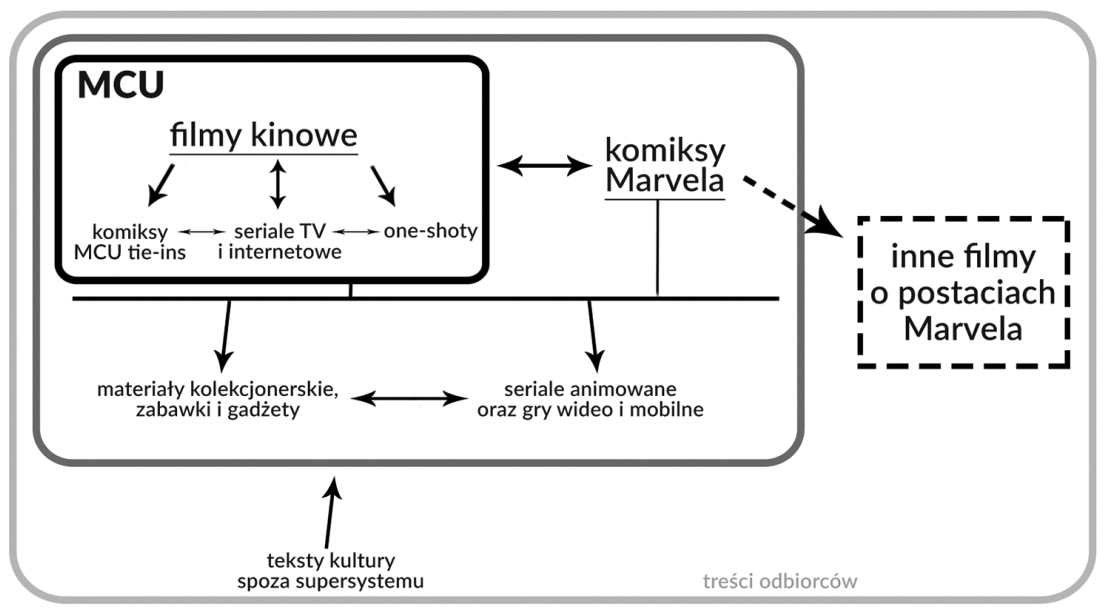

Rycina 3. Zależności między poszczególnymi elementami supersystemu MCU Źródło: opracowanie własne.

Tak przedstawia się - w ogólnym zarysie - specyficzna struktura supersystemu rozrywkowego MCU. Osobną uwagę należy jednak zwrócić na sam trzon tej metanarracji, czyli uniwersum filmowe i jego poszczególne realizacje. Między nimi występują bowiem kolejne zależności organizujące nie tylko charakter adaptacji materiałów komiksowych, lecz także - co wydaje się dużo istotniejsze — sposób recepcji.

\section{Poziomy zależności wewnątrz uniwersum filmowego}

Chronologicznie rzecz ujmując, MCU dzieli się współcześnie na trzy tak zwane fazy. Pierwsza z nich rozwijała się relatywnie powoli w latach 2008-2012 — rozpoczęła ją premiera Iron Mana i miesiąc później filmu The Incredible Hulk (reż. L. Leterrier, USA 2008), później trzeba było czekać dwa lata na Iron Mana 2 (reż. J. Favreau, USA 2010), a następnie rok na filmy Thor (reż. K. Branagh, USA 
2011) i Captain America: Pierwsze starcie (Captain America: First Avenger, reż. J. Johnston, USA 2011). Finałem pierwszej fazy było zebranie bohaterów wszystkich filmów w superprodukcji Avengers (reż. J. Whedon, USA 2012), co zarazem zainicjowało i ustabilizowało sposób konstruowania fabularnych i produkcyjnych zależności pomiędzy poszczególnymi obrazami. Druga faza — przypadająca na lata 2013-2015 - to przede wszystkim kontynuacje solowych filmów o Iron Manie, Thorze i Kapitanie Ameryce, prowadzących do drugiego filmu grupowego (assemble movie) pod tytułem Avengers: Czas Ultrona (Avengers: Age of Ultron, reż. J. Whedon, USA 2015). W owym czasie premiery miały również bardziej „eksperymentalne” produkcje, czyli wspomniani już Strażnicy Galaktyki oraz zrealizowany przy mniejszym budżecie - Ant-Man (reż. P. Reed, USA 2015) ${ }^{30}$. Fazę trzecią rozpoczął w 2016 roku film Kapitan Ameryka: Wojna bohaterów (Captain America: Civil War, reż. A. Russo, J. Russo, USA 2016), o którym będzie mowa w dalszej części tekstu.

Z produkcyjnego punktu widzenia głównym sposobem budowania zależności była do pewnego stopnia stylistyczna jednorodność kolejnych filmów. Nawet jeśli — tak jak Thor Branagha - operowały one fantastyczno-kosmicznym rekwizytorium, pojawiały się w nich pewne elementy pozwalające rozpoznać i umiejscowić daną narrację w kontekście innych produkcji MCU. W pierwszej fazie takim „spoiwem” była agencja S.H.I.E.L.D., obecna w mniejszym lub większym stopniu w każdym filmie MCU, której dyrektor Nick Fury (Samuel L. Jackson) doprowadza w filmie Avengers do powstania tytułowej drużyny. W drugiej fazie udział agencji nie jest już aż tak wyraźny, punktem odniesienia stają się jednak wydarzenia z filmu Whedona - spójność uniwersum przesuwa się zatem w stronę powiązań fabularnych (co pozwala kolejnym reżyserom na większą swobodę twórczą). Poza tym produkcje Marvel Studios cechuje właściwa filmom komiksowym fraktalnośćl hybrydowość gatunkowa, z której uczyniły one niemal swój znak rozpoznawczy, nie bojąc się mieszać konwencji superbohaterskiej z tą właściwą na przykład space operze (Strażnicy Galaktyki), filmowi wojennemu z elementami dieselpunku (Captain America: Pierwsze starcie) czy wręcz fantasy (filmy o Thorze).

Najbardziej istotnym aspektem produkcyjnym cementującym spójność MCU jest jednak ciągłość reprezentacji. Nie licząc trzech przypadków ${ }^{31}$, wszystkie posta-

${ }^{30}$ Budżet filmu Reeda wynosił 130 milionów dolarów, podczas gdy większość produkcji z fazy drugiej kosztowała około 170 milionów, a Iron Man 3-200 milionów (za serwisem Box Office Mojo, boxofficemojo.com, dostęp: 3.08.2017).

${ }^{31}$ Mowa przede wszystkim o zastąpieniu Edwarda Nortona - grającego postać Bruce'a Bannera/Hulka - Markiem Ruffalem, co oznaczało zmianę w obsadzie jednej z głównych postaci MCU (por. The Salaries of Marvel's The Avengers, http://www.therichest.com/expensive-lifestyle/ entertainment/marvels-the-avengers-salaries, dostęp: 5.08.2017). Pozostałe przypadki to zastąpienie Terrence'a Howarda Donem Cheadlem w roli Jamesa Rhodesa w Iron Manie 2 (reż. J. Favreau, USA 2010) oraz Josha Dallasa Zacharym Levim w roli Fandrala w filmie Thor: Mroczny świat (Thor: The Dark World, reż. A. Taylor, USA 2013). Obie role były jednak drugoplanowe (a w wypadku Fandrala nawet epizodyczne), zmiany zaś nastąpiły odpowiednio wcześnie, więc nie wywołało to sprzeciwu 
cie są od początku istnienia tego supersystemu grane przez tych samych aktorów, co zapewnia stałą wizualną reprezentację poszczególnych postaci i pozwala na ich szybką identyfikację nawet nieszczególnie zaznajomionym z nimi odbiorcom. Dzięki temu można też dokonywać pewnych zmian w wyglądzie kostiumów bohaterów (na przykład zbroi Iron Mana) bez ryzyka, że przestaną być rozpoznawalni (a takie zabiegi umożliwiają dywersyfikowanie rynku kolekcjonerskiego, chociażby poprzez wypuszczenie nowej linii zabawek czy figurek z okazji premiery nowego filmu) $)^{32}$.

Tym jednak, co przesądza o efektywności i sugestywności filmowych narracji w MCU, jest ich wewnętrzna spójność fabularna (a przynajmniej brak jawnych sprzeczności). Dzięki licznym zabiegom konstrukcyjnym poszczególne fabuły nie tylko sobie nie przeszkadzają, lecz także wzajemnie do siebie nawiązują i się uzupełniają. To właśnie spójność fabularna przeważała nad stylistyczną w filmach drugiej fazy, konstytuując sposób wzajemnych zależności między poszczególnymi obrazami i - co ważniejsze - sugerując celowość wprowadzania kolejnych wątków. Odbyło się to zarazem z dużym szacunkiem dla widza; sugestie i nawiązania do wydarzeń z innych produkcji były tak nieznaczne, że nie zakłócały przyjemności odbioru (rozpoznanie ich nie było zatem niezbędne, stanowiło zaś wartość dodaną, zwiększającą satysfakcję z recepcji danej fabuły), albo opierały się na pewnych sztywnych warunkach.

Głównym z nich było wyraźnie widoczne założenie, że poszczególne filmy mogą do siebie nawiązywać jedynie mimochodem, w sposób, który nie będzie miał wpływu na fabułę. Dlatego też w filmie Kapitan Ameryka: Zimowy Żotnierz (Captain America: Winter Soldier, reż. A. Russo, J. Russo, USA 2014) pada rzucone mimochodem nazwisko doktora Strange'a, w Doktorze Strange wspomniany jest wypadek ukazany w Iron Manie 2, a w Thorze pada nazwisko Tony'ego Starka, który z kolei pojawia się w scenie po napisach w filmie The Incredible Hulk. Tego typu powiązań jest znacznie więcej — wiele z nich pojawia się na przykład w scenach po napisach — żadne z nich nie wpływają jednak w istotny sposób na konkretną fabułę filmu. Jedyne związki fabularne, które są bardziej eksponowane lub mają istotne

długoletnich fanów MCU. Na marginesie warto wspomnieć jeszcze o dwóch przypadkach rozbieżności obsadowych między filmami a serialami. Aktorka Alfre Woodard wystąpiła w dwóch różnych rolach — w filmie Kapitan Ameryka: Wojna bohaterów jako Miriam Sharpe i serialu Luke Cage (USA 2016-) jako Mariah Dillard. Do roli Tiny Minoru zaangażowano zaś dwie różne aktorki: w filmie Doktor Strange (Doctor Strange, reż. Scott Derrickson, USA 2016) była to Linda Louise Duan, a w nadchodzącym serialu The Runaways - Brittany Ishibashi. Są to jednak rozbieżności występujące poza stricte rozumianym uniwersum filmowym.

32 Takie postacie jak Iron Man znakomicie nadają się do tego typu zabiegów, często bowiem modyfikują i ulepszają swoje stroje; w samym filmie Iron Man Tony Stark buduje trzy warianty swojego pancerza. Na tym jednak nie poprzestaje; w filmie Spider-Man: Homecoming (reż. J. Watts, USA 2017) prezentuje on już 47. wersję swojej zbroi. To on odpowiada również za uzbrojenie i zaplecze technologiczne grupy Avengers, co uzasadnia — z fabularnego punktu widzenia - kolejne modyfikacje kostiumów jej członków, a z perspektywy komercyjnej — produkcję nowych gadżetów; por. J.T. Caldwell, Production Culture: Industrial Reflexivity and Critical Practice in Film and Television, Durham 2008. 
znaczenie, dotyczą filmów o drużynie Avengers, na przykład ukochana Thora Jane Foster — w filmie Thor: Mroczny świat ma pretensje do złego Lokiego o wywołanie rozgrywającej się w Avengers bitwy z kosmitami w Nowym Jorku; wydarzenia z tej bitwy wywołują u Tony'ego Starka traumę, z której musi się on leczyć w Iron Manie 3; w filmie Ant-Man tytułowy bohater odwiedza siedzibę Avengers założoną w filmie Avengers: Czas Ultrona, a w Spider-Man: Homecoming protagonista udaremnia kradzież sprzętu z ich poprzedniej bazy.

Wydaje się zatem, że twórcy supersystemu rozrywkowego MCU przyjęli założenie, iż znajomość filmów o Avengers jest obligatoryjna i centralna dla rozeznania w filmowym (i nie tylko) uniwersum. Teoretycznie produkcje „,ze znacznie większą obsadą — jak Avengers — są bardziej nastawione na akcję i opowieść, więc szczegółowe przedstawianie postaci nie jest konieczne"33. Innymi słowy główny ciężar ekspozycji postaci jest zrzucony na ich solowe filmy, należy jednak zauważyć, że owe assemble movies całkowicie z niego nie rezygnują, zarysowując poszczególnych bohaterów na tyle wyraziście, aby widz był w stanie ich rozpoznać i się z nimi utożsamić (szczególnie widoczne jest to w pierwszym filmie Avengers). Dlatego też w pierwszej i drugiej fazie można było poprzestać na oglądaniu jedynie assemble movies, które były samowystarczalne i zrozumiałe (a jedyne nawiązania do innych produkcji nie wychodziły poza formę napomknień, czego przykładem jest choćby dyskusja Thora i Tony'ego Starka o ich partnerkach - Jane Foster i Pepper Potts — która miała miejsce w Avengers: Czasie Ultrona i była wyłącznie akcentem humorystycznym, choć widz zaznajomiony z solowymi filmami obu bohaterów doskonale zdawał sobie sprawę, o kim mowa).

O ile więc znajomość filmów o Avengers wydaje się kluczowa, o tyle w pozostałych przypadkach w filmach pierwszej i drugiej fazy decydującą rolę odgrywa serialowość MCU w tradycyjnym tego słowa znaczeniu. Widz zainteresowany przygodami na przykład Iron Mana do pełnego ich zrozumienia musiał więc zapoznać się z filmami Iron Man, Iron Man 2, Avengers, Iron Man 3 i Avengers: Czas Ultrona, ale już znajomość fabuł Thora czy filmów o Kapitanie Ameryce nie była niezbędna. Analogicznie rzecz się ma z filmami, których bohaterowie nie pojawiają się w żadnej z odsłon Avengers, jak na przykład Strażnicy Galaktyki - w tym wypadku filmy Whedona dostarczają jedynie kontekstu do pobudek jednego ze złoczyńców - Thanosa. Dzięki temu potencjalny odbiorca supersystemu rozrywkowego MCU nie był zobligowany do znajomości wszystkich filmów pierwszej i drugiej fazy, mógł bowiem dołączyć do śledzenia tej metanarracji w dowolnym momencie, „nadrabiając” jedynie filmy o Avengers. Spójność przedstawianych fabuł byłaby dla takiego modelu recepcji jedynie wartością dodaną, choć — jak już wspomniałem — kluczową (zob. rycina 4).

33 Á. Richter, op. cit. 


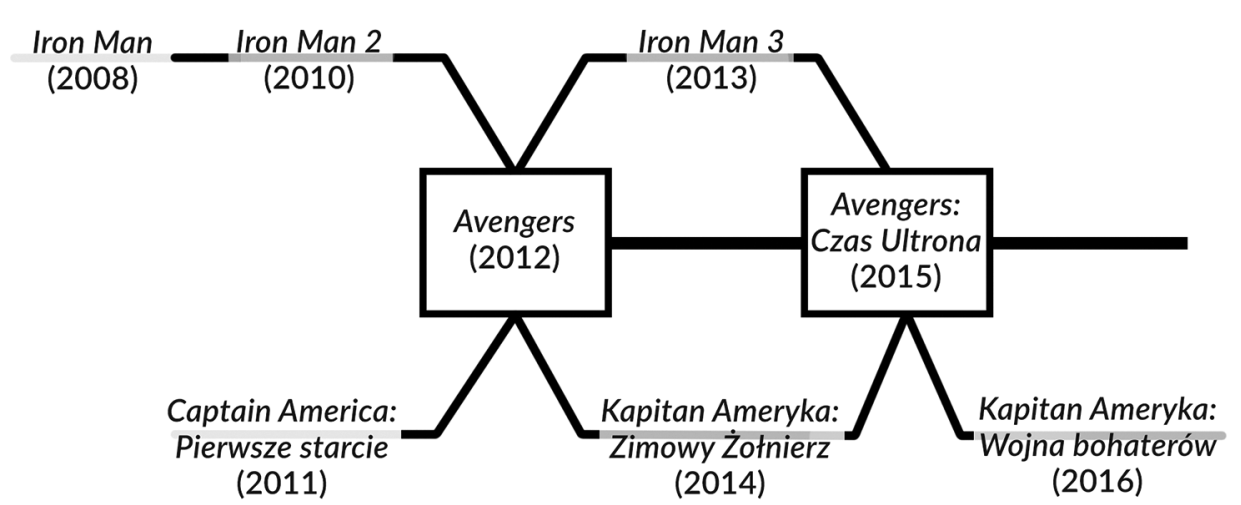

Rycina 4. Struktura powiązań fabularnych wewnątrz uniwersum filmowego MCU

Źródło: opracowanie własne.

Kluczowość ta ma decydujące znaczenie przy spajaniu filmowego uniwersum za pomocą określonych środków fabularnych, a ściślej — pewnych wątków prowadzących do z góry zaplanowanej kulminacji pod koniec fazy trzeciej. Mowa tu przede wszystkim o wątku Kamieni Nieskończoności — potężnych artefaktów, które docelowo ma zebrać wspomniany Thanos w trzeciej części cyklu o Avengers. Wątek ten wplatany jest mniej lub bardziej swobodnie w niektóre produkcje MCU już od pierwszej fazy. W filmie Captain America: Pierwsze starcie wprowadzony zostaje Tesseract, odgrywający też później rolę w filmie Avengers, w którym pojawia się również Berło Lokiego. W Thorze: Mrocznym świecie do listy dołącza Eter, a w scenie po napisach wszystkie artefakty zostają po raz pierwszy nazwane Kamieniami Nieskończoności. Strażnicy Galaktyki wprowadzają czwarty artefakt — Glob — informują też widzów, że artefaktów docelowo będzie sześć, co następnie potwierdza wątek śledztwa Thora w filmie Avengers: Czas Ultrona (gdzie główną rolę odgrywa kamień ukryty w Berle Lokiego). Piąty artefakt, Oko Agamotto, pojawił się w filmie Doktor Strange, szósty zaś pozostaje nierozpoznany. W ten sposób nawet bardzo luźno związane z uniwersum produkcje - jak Strażnicy Galaktyki czy Doktor Strange — dzięki wątkowi Kamieni Nieskończoności przypominają odbiorcom, że ich akcja rozgrywa się w tym samym świecie przedstawionym co na przykład Avengers i że ów świat jest koherentny. Tym samym za pomocą nawiązań o stricte intertekstualnym charakterze twórcy MCU dbają, aby odkrywanie kolejnych odsłon tej metanarracji przynosiło odpowiednią satysfakcję i zachęcało odbiorców do zapoznawania się z całą ofertą filmową (co oczywiście przekłada się na wymierne zyski finansowe), starając się jednocześnie nie zrażać rozmiarem swojego uniwersum. Przynajmniej tak było do trzeciej fazy. 


\section{Zmiany w hierarchii zależności — przypadek Kapitana Ameryki: Wojny bohaterów}

Jak zauważa Żaglewski, trzeci film o Kapitanie Ameryce - Wojna bohaterów braci Russo z 2016 roku — jest wyjątkowy ze względu na zespół czynników konstytuujących filmowo-komiksowe uniwersum, a w szerszej, interesującej nas perspektywie - cały supersystem rozrywkowy MCU. Pojawia się wiele - tak istotnych do umocowania narracji w szerszym kontekście kulturowym - nawiązań czy przetworzeń motywów z kultury popularnej, na czele z jawnym odniesieniem do Imperium kontratakuje (The Empire Strikes Back, reż. I. Kershner, USA 1980), kultowego epizodu sagi „Gwiezdne Wojny”, uznawanego przez wielu odbiorców za najlepszą część tego cyklu. Oto w monumentalnej scenie walki na lotnisku w Lipsku podczas starcia dwóch grup superbohaterów Spider-Man wpada na pomysł pokonania Ant-Mana (który dzięki możliwościom swojego kostiumu urósł do rozmiarów giganta), zaczerpnięty z sekwencji bitwy o Hoth, ukazanej w piątej części „Gwiezdnych Wojen”34. Nawiązanie to jest wypowiedziane przez Spider-Mana otwartym tekstem i stanowi nie tylko odniesienie do popkulturowej erudycji odbiorcy (który odczuwa satysfakcję dzięki jego rozpoznaniu), lecz także buduje swego rodzaju wspólnotę przeżyć z bohaterami filmu, którzy mają analogiczne doświadczenia z tekstami kultury — również widzieli Imperium kontratakuje i również (prawdopodobnie) uważają ten film za kultowy. Zabieg ten wpływa znacząco na skrócenie dystansu między postacią a widzem i potęguje działanie mechanizmu projekcji-identyfikacji.

W filmie pojawiają się też liczne nawiązania do medium pierwotnego, przede wszystkim do komiksu Marka Millara i Stevena McNivena Wojna domowa z 2007 roku. Dotyczy to przede wszystkim osnowy fabularnej — w obu mediach motywem przewodnim jest konflikt między Kapitanem Ameryką a Iron Manem o kwestie związane z prowadzoną przez rząd (w filmie - ONZ) rejestracją superbohaterów. Ze względu na narastające przez lata odmienne sposoby myślenia i działania - Iron Man jest zwolennikiem ograniczania wolności na rzecz bezpieczeństwa, Kapitan Ameryka jest apologetą wolności jednostki — dyskusja wkrótce przeradza się w konflikt, w którym poszczególni superbohaterowie Marvela muszą zająć jakieś stanowisko. W komiksową Wojnę domowa angażują się dziesiątki bohaterów, w Wojnie bohaterów bierze udział jedynie dwunastu (w tym po raz pierwszy zaprezentowani widowni Czarna Pantera i Spider-Man ${ }^{35}$ ), wynika to jednak przede wszystkim ze specyfiki medium oraz faktu, że istnie-

34 Pomysł polegał na oplątaniu gigantycznemu Ant-Manowi nóg, dzięki czemu wspólny atak dwóch innych superbohaterów był w stanie zaburzyć jego równowagę. Analogiczną metodę stosowali piloci Rebelii podczas walki ze znacznie większymi machinami kroczącymi Imperium w filmie Kershnera.

35 A ściślej jego inkarnacja działająca w ramach MCU, niezależna od tych wersji Człowieka-Pająka, które pojawiały się w filmach wytwórni Sony w latach 2002-2014. 
jące od ośmiu lat MCU nie zdążyło wykreować tylu superbohaterskich postaci, ile wydawane od lat sześćdziesiątych XX wieku komiksy Marvela. Oczywiście obok inspiracji fabularnych — które każą traktować Wojnę bohaterów jako luźną adaptację Wojny domowej - występuje szereg cytatów tekstowych i graficznych, na czele z kadrem ukazującym Kapitana Amerykę zasłaniającego się tarczą przed atakiem Iron Mana, inspirowanym okładką siódmego zeszytu komiksu Millara i McNivena ${ }^{36}$.

Najistotniejsza jednak z naszego punktu widzenia jest struktura fabularna filmu w ramach MCU, wynikająca z tego, że Wojna bohaterów jest zarazem trzecim obrazem o Kapitanie Ameryce oraz trzynastą produkcją osadzoną w Kinowym Uniwersum Marvela. Zgodnie ze strukturą filmów pierwszej i drugiej fazy do rozeznania w fabule konieczna byłaby zatem znajomość poprzednich dwóch filmów o Kapitanie Ameryce oraz obu obrazów o Avengers. Fakt, że głównym antagonistą Kapitana jest w filmie Iron Man, sugerowałby również konieczność zapoznania się z trzema filmami o tej postaci, jednak otrzymuje ona relatywnie długą i rozbudowaną scenę ekspozycyjną w pierwszym akcie filmu, która przy znajomości fabuł pozostałych kinowych realizacji o Avengers - przede wszystkim Czasu Ultrona - wystarczy do rozeznania się w fabule Wojny bohaterów ${ }^{37}$. Nieco bardziej problematyczną kwestią jest wspomniana wcześniej rola Ant-Mana $\mathrm{i}$ jej znaczenie dla fabuly. Nie tylko bowiem pojawia się on praktycznie bez żadnej ekspozycji, ale jego udział zmienia też wynik starcia na lotnisku w Lipsku w trzecim akcie filmu. Tym samym widzowie niezapoznani z filmem Ant-Man mogą się poczuć zagubieni i potraktować udział tej postaci jako swego rodzaju deus ex machina. W gruncie rzeczy — jak się okazuje — twórcy filmu liczyli się $\mathrm{z}$ taką ewentualnością:

Na samym początku prac musieliśmy zaakceptować fakt, że zgadzamy się na utratę tej części widzów, którzy są „prawiczkami”, jeśli chodzi o nasze uniwersum [...]. Nie mogliśmy jednak pójść serialowym tropem przypominania tego, co wydarzyło się w „,poprzednich odcinkach Kinowego Uniwersum Marvela”, ponieważ zabrałoby to jakieś 25 minut $^{38}$.

Płynie z tego wniosek, że w miarę rozwoju filmowego uniwersum w ramach supersystemu rozrywkowego MCU coraz częściej będzie dochodzić do sytuacji, w której swobodne zapoznanie się z fabułą danej produkcji nie będzie możliwe bez znajomości chociaż części wcześniejszych filmów. Wszystko wskazuje na to, że taką

36 M. Cecchini, Captain America: Civil War - Complete Marvel Universe Easter Eggs and References Guide, http://www.denofgeek.com/us/books-comics/captain-america/255004/captain-americacivil-war-complete-marvel-universe-easter-eggs-and-references-guide (dostęp: 7.08.2017).

37 Oczywiście znajomość solowych filmów o Iron Manie zwiększa satysfakcję z seansu ze względu na pełniejsze rozumienie tej postaci, podobnie jak rozpoznanie w jednym z bohaterów epizodycznych, Thaddeusie Rossie, generała będącego przeciwnikiem Hulka w The Incredible Hulk.

38 K. Phegley, Captain America: Civil War Writers Admit New Viewers May Be Lost... And That's $O K$, http://www.cbr.com/captain-america-civil-war-writers-admit-new-viewers-may-be-lostand-thats-ok, cyt. za: T. Żaglewski, op. cit., s. 254. 
produkcją będzie planowany na maj 2018 roku film Avengers: Wojna bez granic (reż. A. Russo, J. Russo); nie tylko bowiem zbiorą się w nim postacie z wielu innych produkcji (na czele z obiema częściami Strażników Galaktyki ${ }^{39}$ ), lecz także będzie to film kumulujący rozsiane dotąd po uniwersum wątki związane z Kamieniami Nieskończoności. Zachodzi więc podejrzenie, że do pełnego zrozumienia fabuły niezbędna będzie znajomość większości (o ile nie wszystkich) dotychczasowych produkcji MCU. Ta spadająca siłą rzeczy inkluzywność rdzenia supersystemu rozrywkowego, jaką jest filmowe uniwersum MCU, wydaje się nieuniknioną konsekwencją rozwoju synchronicznego i diachronicznego struktury fabularnej tej metanarracji. Zarazem może się okazać, że hierarchizacja poszczególnych serii wewnątrz uniwersum straci na znaczeniu; tak jak relatywnie niskobudżetowy Ant-Man okazał się niezbędny, aby w pełni zadowolić się fabułą trzeciego filmu o Kapitanie Ameryce.

\section{Podsumowanie}

Reasumując, można przedstawić strukturę supersystemu rozrywkowego MCU w następujący sposób:

- trzonem supersystemu jest uniwersum filmowe, u którego rdzenia w pierwszej i drugiej fazie znajdowały się filmy o Avengers; trzecia faza może ten model zmodyfikować;

— inne wchodzące w skład MCU teksty kultury — przede wszystkim seriale telewizyjne oraz komiksowe uzupełnienia - opierają się na rozwiązaniach fabularnych uniwersum filmowego i często się do nich odnoszą, stanowią jednak przede wszystkim wartość dodaną (ich znajomość nie jest zatem niezbędna do satysfakcjonującego odbioru filmów);

- MCU funkcjonuje na zasadzie sprzężenia zwrotnego z komiksowym uniwersum Marvela - czerpie z niego postacie, wzorce fabularne i ikonograficzne, samo zaś jest również źródłem (przede wszystkim graficznych) inspiracji dla komiksowych artystów; dąży tym samym do ujednolicenia wizerunku komiksowych bohaterów z ich filmowymi odpowiednikami, aby poprawić koherencję i zredukować dysonans poznawczy u potencjalnych odbiorców, a tym samym zwiększyć zyski ze sprzedaży;

— inne narracyjne teksty kultury, jak gry wideo i (zwłaszcza) seriale animowane, czerpią zarówno z filmowych, jak i komiksowych wzorców; służą jednak przede wszystkim za narzędzie podsycające zainteresowanie supersystemem;

- podobną funkcję mają materiały kolekcjonerskie, zabawki i gadżety, a więc wszystkie przedmioty, które fani - związani emocjonalnie z którymś z bohaterów - pragną posiadać; również ta część supersystemu w znaczący sposób wpływa na jego wyniki finansowe;

39 Por. P. Sciretta, Which Characters Will (And Won't) Appear in Avengers: Infinity War, http:// www.slashfilm.com/avengers-infinity-war-cast (dostęp: 6.08.2017). 
— supersystem rozrywkowy MCU koresponduje też z wieloma tekstami kultury spoza filmowo-komiksowego uniwersum, wpisując się niejako w świadomość kulturową fanów;

— w jego ramach mieszczą się również wszelkie przejawy oddolnej aktywności fanowskiej, nie tylko wpływając dodatnio na rozpoznawalność supersyste$\mathrm{mu}$, ale też pełniąc funkcję socjalizacyjną;

- wreszcie niejako obok supersystemu rozrywkowego MCU znajdują się inne produkcje filmowe stworzone na podstawie własności intelektualnej Marvela, które również opierają się na materiale komiksowym i niejednokrotnie służą za kontekst do obrazów Kinowego Uniwersum Marvela.

Jak więc widać, supersystem rozrywkowy MCU jest strukturą niezwykle skomplikowaną, o wielowątkowej sieci wzajemnych relacji i powiązań, której złożoność jest dodatkowo funkcją czasu, to znaczy, że wraz z rozwojem komiksowo-filmowego uniwersum struktura ta będzie dodatkowo się nawarstwiać. Niewykluczone, że pojawią się nowe poziomy, na przykład gry wideo otrzymają nieco inny status niż seriale (jak dzieje się w wypadku na przykład supersystemu opartego na marce Wiedźmin). Ponieważ MCU jest obecnie najbardziej dochodową marką w historii kina (wartą 12 miliardów dolarów ${ }^{40}$ ), jej dalszy rozwój a wraz z nią całego tego supersystemu rozrywkowego — wydaje się nieuchronny.

\section{Bibliografia}

\section{Opracowania}

Caldwell J.T., Production Culture: Industrial Reflexivity and Critical Practice in Film and Television, Duke Iniversity Press, Durham 2008.

Flanagan M., McKenny M., Livingstone A., The Marvel Studios Phenomenon: Inside a Transmedia Universe, Bloomsbury Publishing, London 2016.

Garneau E., Dare to be stupid: The fetishization of heavy metal and the new in Transformers: the Movie, [w]: Marvel Comics into Film: Essays on Adaptations Since the 1940s, red. M.J. McEniry, R.M. Peaslee, R.G. Weiner, McFarland \& Company Inc., Jefferson 2016, s. 52-59.

Jenkins H., Kultura konwergencji. Zderzenie starych i nowych mediów, przeł. M. Bernatowicz, M. Filiciak, Wydawnictwa Akademickie i Profesjonalne, Warszawa 2007.

Johnson D., Cinematic destiny: Marvel Studios and the trade stories of industrial convergence, „Cinema Journal” 52, 2012, s. 1-24.

Kinder M., Playing with Power in Movies, Television, and Video Games: From Muppet Babies to Teenage Mutant Ninja Turtles, University of California Press, Berkeley 1991.

Kluszczyński R., Interaktywność - właściwość odbioru czy nowa jakość sztuki/kultury, [w:] Estetyczne przestrzenie wspótczesności, red. A. Zeidler-Janiszewska, Instytut Kultury, Warszawa 1996, s. 143-153.

40 Por. R. Cain, The Marvel Cinematic Universe Just Topped \$12 Billion in Worldwide Box Office, https://www.forbes.com/sites/robcain/2017/07/10/the-marvel-cinematic-universe-has-now-topped-12billion-in-total-worldwide-gross/\#5e333bd77775 (dostęp: 6.08.2017). 
Maffesoli M., Czas plemion. Schyłek indywidualizmu w społeczeństwach ponowoczesnych, red. B. Fatyga, przeł. M. Bucholc, Wydawnictwo Naukowe PWN, Warszawa 2008.

Major M., Serialowy fan 2.0, „Ekrany” 2012, nr 10, s. 86-87.

Pellizzi V., Entertainment Marketing Strategy: Transmedia Storytelling, Marvel and the Reinvention of the Entertainment Franchise, praca napisana pod kierunkiem B. Mierzejewskiej, Fordham University, New York 2015.

Wałaszewski Z., Wiedźmin: pierwszy polski supersystem rozrywkowy, [w:] Obraz literatury w komunikacji społecznej po roku '89, red. A. Werner, T. Żukowski, Wydawnictwo IBL PAN, Warszawa 2013, s. 126-154.

Wolski M., Kino przerysowane. Strategie przenoszenia komiksów na ekran na przykładzie filmów firmy Marvel Studios, [w:] Bękarty X muzy. Filmowe adaptacje materiatów nieliterackich, red. P. Duziński, R. Dudziński, K. Kowalczyk, Stowarzyszenie Badaczy Popkultury i Edukacji Popkulturowej „Trickster”, Wrocław 2015, s. 11-28.

Żaglewski T., Kinowe uniwersum superbohaterów. Analiza współczesnego filmu komiksowego, Wydawnictwo Naukowe PWN, Warszawa 2017.

\section{Filmografia}

Agenci T.A.R.C.Z.Y. (Agents of S.H.I.E.L.D.), reż. J. Whedon et al., USA 2013.

Agentka Carter (Agent Carter), reż. J. Getzinger et al., USA 2015-2016.

Ant-Man, reż. P. Reed, USA 2015.

Avengers, reż. J. Whedon, USA 2012.

Avengers: Czas Ultrona (Avengers: Age of Ultron), reż. J. Whedon, USA 2015.

Avengers: Zjednoczeni (Avengers Assemble), USA 2013.

Captain America: Pierwsze starcie (Captain America: First Avenger), reż. J. Johnston, USA 2011.

Ciekawa rzecz spotkata nas przy młocie Thora (A Funny Thing Happened on the Way to Thor's Hammer), reż. Leythum, USA 2011.

Doktor Strange (Doctor Strange), reż. S. Derrickson, USA 2016.

Imperium kontratakuje (The Empire Strikes Back), reż. I. Kershner, USA 1980.

The Incredible Hulk, reż. L. Leterrier, USA 2008.

Iron Man, reż. J. Favreau, USA 2008.

Iron Man - obrońca dobra (Iron Man: The Animated Series), reż. B. Arkwright et al., USA 19941996.

Iron Man 2, reż. J. Favreau, USA 2010.

Iron Man 3, reż. S. Black, USA 2013.

Kapitan Ameryka: Wojna bohaterów (Captain America: Civil War), reż. A. Russo, J. Russo, USA 2016.

Kapitan Ameryka: Wojna bohaterów (Captain America: Civil War), reż. A. Russo, J. Russo, USA 2016.

Kapitan Ameryka: Zimowy Żotnierz (Captain America: Winter Soldier), reż. A. Russo, J. Russo, USA 2014.

Konsultant (The Consultant), reż. Leythum, USA 2011.

Spider-Man: Homecoming, reż. J. Watts, USA 2017.

Strażnicy Galaktyki (Guardians of the Galaxy), reż. J. Gunn, USA 2014.

Thor, reż. K. Branagh, USA 2011.

Thor: Mroczny świat (Thor: The Dark World), reż. A. Taylor, USA 2013.

Literatura i Kultura Popularna 25, 2019

(C) for this edition by CNS 


\section{Źródla internetowe}

Cain R., The Marvel Cinematic Universe Just Topped $\$ 12$ Billion In Worldwide Box Office, https:// www.forbes.com/sites/robcain/2017/07/10/the-marvel-cinematic-universe-has-now-topped12-billion-in-total-worldwide-gross/\#5e333bd77775 (dostęp: 6.08.2017).

Cecchini M., Captain America: Civil War - Complete Marvel Universe Easter Eggs and References Guide, http:/www.denofgeek.com/us/books-comics/captain-america/255004/captain-americacivil-war-complete-marvel-universe-easter-eggs-and-references-guide (dostęp: 7.08.2017).

Iron Man in other Media, https://en.wikipedia.org/wiki/Iron_Man_in_other_media (dostęp: 2.08.2017).

June 2017 Comic Book Sales to Comics Shops, http://www.comichron.com/monthlycomicssales/2017/2017-06.html (dostęp: 24.07.2017).

Ochnik M., \#2351 — Marvel podzielony, http://kolorowezeszyty.blogspot.com/2017/07/2351-marvel-podzielony.html (dostęp: 24.07.2017).

Phegley K., Captain America: Civil War Writers Admit New Viewers May Be Lost... And That's OK, http://www.cbr.com/captain-america-civil-war-writers-admit-new-viewers-may-be-lost-andthats-ok (dostęp: 7.08.2017).

Richter Á., The Marvel Cinematic Universe as a transmedia narrative, „Americana: E-Journal of American Studies in Hungary" 12, 2016, http://americanaejournal.hu/vol12nol/richter (dostęp: 3.08.2017).

Ryan M.L., Transmedial Storytelling and Transfictionality, http://users.frii.com/mlryan/transmedia. html (dostęp: 8.06.2015).

The Salaries of Marvel's The Avengers, http://www.therichest.com/expensive-lifestyle/entertainment/marvels-the-avengers-salaries (dostęp: 5.08.2017).

Sciretta P., Which Characters Will (And Won't) Appear in Avengers: Infinity War, http://www.slashfilm.com/avengers-infinity-war-cast (dostęp: 6.08.2017).

Stelmach Ł., Dlaczego Fox powinien sprzedać prawa Marvelowi?, http://ichabod.pl/dlaczego-foxpowinien-sprzedac-prawa-marvelowi/ (dostęp: 2.08.2017).

WHIH Newsfront, https://twitter.com/whihofficial (dostęp: 2.08.2017).

\section{Levels of mutual influences in the entertainment supersystem of the Marvel Cinematic Universe}

Summary

This paper focuses on mutual influences between respective elements of the MCU (Marvel Cinematic Universe) entertainment supersystem and their crucial role in determining what a said supersystem actually is and how it is constructed. Its inherent complexity - obvious even to an inexperienced observer - develops both in space and time. It is because the MCU supersystem exists as a web of mutual connections and relations, and every new addition to the system increases its complexity. The paper also aims to determine, how non-textual factors (such as legal, marketing, or commercial) interfere with development strategies of the Marvel Cinematic Universe. 